Fisioter Bras 2017;18(1):C1

\title{
EDITORIAL
}

\section{Caminhos para a normatização do Método Pilates no Brasil}

Jefferson Fagundes Loss, D.Sc.

Editor do Caderno Pilates, Professor Associado da Universidade Federal do Rio Grande do Sul

Endereço para correspondência: jefferson.loss@ufrgs.br

Está no ar mais uma edição do Caderno Pilates! Estamos passando por momento histórico em nosso país, não apenas do ponto de vista econômico, político e social, mas também no campo das ciências. Neste contexto de efervescentes mudanças o Pilates está também contemplado.

Há um movimento chamado Pilates com Qualidade, cuja iniciativa devese principalmente a professora Silvia Gomes, que está organizando para o primeiro semestre de 2017 um encontro de educadores de todo o Brasil, que trabalham com Pilates, com a finalidade de discutir a formação e o ensino do Pilates no Brasil. Também há outro grupo, nascido nas redes sociais a partir da iniciativa do advogado Robson Alcova, intitulado Pilates Legal, que busca a normatização da atividade do Método Pilates no Brasil.

Neste fervilhar de discussões, a Atlântica Editora disponibiliza o Caderno Pilates, encartado dentro da Revista Fisioterapia Brasil, de forma eletrônica e totalmente disponível para consultas on-line! Parabéns à editora por mais esta iniciativa. Os leitores passam a contar, além do espaço específico para informações científicas a respeito do Método Pilates, com a versatilidade e velocidade que a internet proporciona. Porém, como em todo começo de jornada, diversas barreira e dificuldades devem ser superadas, até que consigamos atingir a qualidade esperada e merecida pelo nosso tão amado Método Pilates. Erros e acertos são inevitáveis, e esperamos contar com a compreensão de todos, pois trabalhamos na direção de minimizar os erros e exacerbar os acertos.

Aproveito a ocasião para agradecer imensamente ao grupo de trabalho da editora e aos professores do conselho editorial, cujo empenho é fundamental neste momento de transição e consolidação desta nova plataforma de divulgação e discussão científica que é o Caderno Pilates. Desejo a todos uma boa leitura. 